\title{
Self Reliance Health Care Students of Miftahul Huda Islamic Boarding School Indramayu Through Cultivation and Processing of Family Medicinal Plants (Toga)
}

\author{
$1^{\text {st }}$ Ulinniam \\ Biology Education Study Program \\ STKIP Pangeran Dharma Kusuma \\ Segeran Juntinyuat \\ Indramayu, Indonesia \\ ulinniam@stkippadhaku.ac.id \\ $4^{\text {th }}$ I D Sopwan \\ Biology Education Study Program \\ STKIP Pangeran Dharma Kusuma \\ Segeran Juntinyuat \\ Indramayu, Indonesia
}

\author{
$2^{\text {nd }} \mathrm{Y}$ A Sari \\ Biology Education Study Program \\ STKIP Pangeran Dharma Kusuma \\ Segeran Juntinyuat \\ Indramayu, Indonesia
}

$5^{\text {th }}$ Yasin

Biology Education Study Program

STKIP Pangeran Dharma Kusuma Segeran Juntinyuat

Indramayu, Indonesia

\author{
$3^{\text {rd }} \mathrm{N}$ W E Juliani \\ Biology Education Study Program \\ STKIP Pangeran Dharma Kusuma \\ Segeran Juntinyuat \\ Indramayu, Indonesia
}

\begin{abstract}
Health development is an effort carried out by all components society aimed at increasing awareness, willingness, and ability to live healty. One of the efforts to support success in health develpment is to implement self reliance health care program for Islamic boarding school students through the cultivation and processing of family medicinal plants. However, the problems found in the implementation of the self reliance program of health care for students of islamic boarding school are lack of self reliance of health care for students, knowledge about family medicinal plants, ways of cultivation through appropriate and friendly technology the environment and its benefits for health, and how to process family medicinal plants into products that are beneficial to health and have economic value. Qualitative and quantitative approach was conducted to collect primary and secondary data. It was observed that the indicators with the highest achievement were indicators of exercise and consumption vegetables and fruits $25.85 \%$ and $8.84 \%$. it means that cultivation and processing of family medicinal plants can increasing self reliance health care program for Islamic boarding school students. Keywords : Self reliance health care's student; Family medicinal plants (toga).
\end{abstract}

Keywords-Self Reliance, Students, Miftahum Huda, Toga

\section{INTRODUCTION}

Health development is an effort carried out by all components of society aimed at increasing awareness, willingness and ability to live a healthy life for everyone in order to realize the highest degree of public health, as an investment for the development of human resources that are socially and economically productive [1]. The success of this health development cannot be separated from developments in science and technology, which have led to increased community productivity, decreased mortality due to illness and increased life expectancy. One effort to support success in health development is to implement an self reliance health care program for Islamic boarding schools.

Self reliance of health care can be done by providing knowledge and skills about clean and healthy living behavior through the cultivation of family medicinal plants (Toga). Clean and healthy living behavior (PHBS) needs to be applied in various places where a group of people live, work, play and interact with each other so the degree of health can increase and the productivity of a group of people occupying these various places will increase [2]. One of the PHBS indicators based on the Ministry of Health of the Republic of Indonesia [3], is by eating fruits and vegetables every day that are highly nutritious and can function as medicine. This indicator can be done by providing family medicinal plants in the boarding school environment.

Islamic boarding school is an Islamic educational institution with a boarding system, where students make the kyai as the central figure developed indigenous by Indonesian people. Pesantren is able to become a multifunctional institution, not only struggling for the development of Islamic education, but also contributing to the progress of the development of the surrounding environment, which includes social, economic, technological, health and ecological fields, even some 
pesantren have been able to uplift the lives of the surrounding community [4]. The specialty of education in the pesantren environment is students are required to be able to live independently through life skill based education. Based on a situation analysis it is known that the Miftahul Huda Segeran Islamic Boarding School is located in Segeran Kidul Village, Juntinyuat District, Indramayu Regency, located $25 \mathrm{~km}$ east of Indramayu City, which is built on 5 hectares of land and has 127 students consisting of 43 male students and 84 female students.

Problems that exist in Miftahul Huda Islamic Boarding School are lack of self reliance students health care, lack of students knowledge about family medicinal plants and their uses, ways of cultivation through appropriate and environmentally friendly technology as well as its health benefits, utilization of yards that have not been used optimally. Efforts to use the yard to support the students life skills are only carried out by cultivating chillies, but the chili plants are only allowed to grow on their own without special care. The development of various innovations related to the plot of land has not been done much because there is no training program on crop cultivation.

The development of this plot of land can be done through plant cultivation through appropriate and environmentally friendly technology that uses the concept of permaculture. Permaculture is a concept that maintains the integrity of harmonization between nature and humans that is permanent [5]. Plant cultivation that will be carried out is the cultivation of family medicinal plants.

Family medicinal plants (TOGA) are plants that are cultivated both in the yard or garden that have medicinal properties. During this time, most people, especially students only know the use of medicinal plants as herbal medicine, even though this family medicinal plant can also be used as a spice in the kitchen and also has the potential as a food or beverage product that is delicious, nutritious and has economic value.

\section{PURPOSE}

The purpose of this community service is to increase the health self reliance of the Miftahul Huda Islamic Boarding School students in Indramayu through the development of family medicinal plants as a means of cultivation training, provision of family medicinal plantations, provision of processed products, and professionally managed so all students are able to participate. Benefits of carrying out community service are increasing the self reliance of students health care, developing the production of processed medicinal plants, and developing the Miftahul Huda Islamic Boarding School as Segeran Indramayu as a center for cultivating family medicinal plants and a reference for cultivation education.

\section{METHOD}

The method used are survey and descriptive method, the method used to conduct an examination that takes place in the field or research location. The workings of the activity implementation are as follows:

\section{A. Preparation Stage}

Location survey aims to identify the need for materials and equipment to increase the self reliance of health care for students, coordinate with leaders and administrators of Islamic boarding schools to design the implementation of programs and activities, purchase materials and equipment for activities, compile all training materials into a module, and prepare materials and equipment the activities.

B. Implementation Stage

PHBS Training: (i) Training on PHBS theory and practice. (ii) Submission of materials and means of cultivation of family medicinal plants. (iii) Training in the cultivation of family medicinal plants. (iv) Training on processing various family medicinal plant products.

\section{DATA ANALYSIS}

Data obtained were analyzed using quantitative and qualitative descriptive analysis.

\section{RESULT AND DISCUSSION}

\section{A. Result}

\section{PHBS Theory and Practice Training.}

Training was carried out well for 3 times face to face in the form of conducting a short training, started from theory, practice and ended with a display as a form of motivation to participants. Training material has been prepared according to the needs of the material provided consisting of two parts, theory and practice. This material is then arranged into a module that will facilitate participants in learning it. Table I. is the the results analysis of PHBS indicator questions :

TABLE I. RESULT ANALYSIS OF PHBS INDICATOR QUESTIONS

\begin{tabular}{|l|l|l|l|l|}
\hline \multirow{2}{*}{ PHBS indicator } & Before & No (\%) & After & Yes (\%) \\
\cline { 2 - 5 } & Yes (\%) & 25.85 & 100 & 0 \\
\hline Exercise & 74.15 & 10.20 & 98.64 & 1.36 \\
\hline $\begin{array}{l}\text { Vegetables and } \\
\text { fruits consumption }\end{array}$ & 89.80 & 4.76 & 98.64 & 1.36 \\
\hline $\begin{array}{l}\text { Dispose waste in its } \\
\text { place }\end{array}$ & 95.24 & 6.10 & 100 & 0 \\
\hline Hand wash & 93.90 & 83.67 & 12.24 & 87.76 \\
\hline Smoke & 16.33 & & \\
\hline
\end{tabular}

2. Training on Family Medicinal Plant Cultivation (TOGA).

The training can be implemented well, this training consists of theoretical and practical training in the cultivation of family medicinal plants (creating a family medicinal plant garden) using the concept of permaculture. The training was held 4 times face to face. The training methods used are lectures, questions and answers, discussion and practice. This training starts from the formation of groups and administrators of TOGA, 
making TOGA gardens, planting TOGA, and labeling or labeling the names of plants to make it easier to recognize and know the types of TOGA.

\section{Training on Processing of Various Family Medicinal} Plant Products (TOGA).

Training of skills to process a variety of TOGA products is carried out well for 3 times face to face in the form of brief training. The training starts from theory, practice and ends with a display as a form of motivation to participants. The theoretical stage to increase knowledge focuses on cognitive abilities. The material provided is a) Processing of various TOGA products, b) Knowledge of materials, c) Packaging and Labeling, and d) Sanitation hygiene as a means of producing good food. The giving of material begins with an explanation and demonstration of how to make the product, then participants are invited to do their own way of making products from preparation to finished products and ready for consumption. The results of the finished products are then evaluated together so that participants become aware of the advantages and disadvantages of the products that have been made. Thus they also gain knowledge about the characteristics of each product. After the finished product is continued with packaging and labeling. The following are the processed products:

TABLE II. SPECIES AND PROCESSED PRODUCT OF TOGA

\begin{tabular}{|l|l|l|l|}
\hline Species & Local name & Processing method & Food product \\
\hline Zingiber officinale & Ginger & Peel, grate & Ginger dodol \\
\hline Amaranthus spinosus & Spinach & Wash, cut & Spinach chips \\
\hline Capsicum annuum & Red Chili & Seed disposal, wash, soak & Candied chili \\
\hline Moringa oleifera & Moringa & Wash, drying, crushing & Nastar and moringa sponge cake \\
\hline
\end{tabular}

environmental damage. Littering can also have an impact

\section{B. Discussion}

\section{PHBS Training.}

Based on the results of the analysis there was an increase in exercise indicators that is equal to $25.85 \%$. The PHBS training is able to improve exercise indicators indicating that students have understood the importance of exercising to maintain health his body. This is in line with Natsir [6] which states that, exercise can improve the function of organs such as the heart, blood vessels, lungs, muscles, bones; joints, improvement of metabolism in the body, reduce body fat and cholesterol leveling. Exercise causes a person to be more resistant to stress and better able to concentrate. This is caused by increased blood supply and decreased salt levels in the brain.

An increase in the indicator of vegetable and fruit consumption was $8.84 \%$. PHBS training is also able to increase the consumption of fruit and vegetables in students, although there are still some students who still do not like fruit and vegetable consumption but there are still more who consume them. Vegetables and fruit are a source of food that is very beneficial for the body. Especially in supporting the need for vitamin intake. Vitamins are a group of organic compounds that are not included in the group of proteins, carbohydrates or fats that cannot be produced by our body [7].

There was also an increase in the hand washing indicator which was $6.10 \%$, although it was small, it showed that students could wash their hands properly and know the benefits of washing their hands. This is consistent with Maryunani [8] which states that washing hands is one of the most basic techniques to prevent the entry of germs into the body.

An increase in the indicator to dispose of waste in its place, which is $3.40 \%$. Before this community service activity was carried out, students were aware of the importance of environmental cleanliness so that after the service was carried out more and more students understood and understood the meaning of environmental cleanliness. The negative impact caused by littering is flooding, disease outbreaks and of course other on air pollution which can damage the ozone layer [9]

Unlike the other PHBS indicators, the smoking indicator decreased by $4.09 \%$. this shows that there is a decrease in male students who smoke. At the Miftahul huda Islamic boarding school there are 43 male students consisting of several ages. Smoking behavior is strongly influenced by the social environment, family and social friends. The most influential factor for adults to stop smoking so far is reinforcing factors, including social environment, addiction and role family. Several studies have shown that friends have the strongest influence on adolescent smoking behavior compared to mass media and family [10].

\section{TOGA Cultivation Training.}

The establishment of a medicinal garden is intended to provide an example of managing a medicinal garden for students and also for community empowerment (students of islamic boarding school) in order to improve health. After planting the medicinal plants, a group schedule will be formed to carry out routine plant maintenance and take turns so that the plants can grow well.

Planting medicinal plants is done by listing medicinal plants to be planted and determined the expected properties of plants. Some of the plants planted include ginger, chili, spinach, moringa and so on. Planting medicinal plants begins with preparing the land that will be used for the TOGA garden. Furthermore, the provision of medicinal plant seeds which is efficacious as medicine is then planted in the garden area in a mutual cooperation by all members of the TOGA group so that the activities can run effectively and efficiently. After that the labeling of the names of plants and the efficacy of these plants is carried out for treatment so that it can add insight for students who want to take advantage of these plants.

3. Training on Processing of Various Family Medicinal Plant Products (TOGA).

This training produced various processed products from TOGA. The products produced include ginger dodol, spinach chips, candied chili, moringa leaf nastar and 
moringa leaf sponge. The types of family medicinal plants found in Indonesia, especially Indramayu, are very diverse, but there are still many people in this case students who know about the types of family medicinal plants, because they think that TOGA can only be found in processed herbal medicine. So when the students were given training on the processing of various TOGA products, they were very interested and very enthusiastic.

The expected output in the self reliance activities of the students' health care is students have cognitive, affective and psychomotor competence in cultivating and utilizing family medicinal plants into a variety of processed foods that are healthy, delicious, nutritious and interesting. While the outcome as a continuation is expected that the cultivation and utilization activities as food ingredients that have a sale value and long-term can help improve the self reliance of health care for students.

\section{CONCLUSION}

These community service activities can run well and are beneficial, especially in terms of increasing the health self reliance students of the Miftahul Huda Islamic Boarding School, Segeran indramayu through the development of family medicinal plant cultivation as a means such as training or cultivation education, provision of family medicinal plant gardens, provision of processed products, and managed professionally so that all students are able to participate.

\section{ACKNOWLEDGMENTS}

Thank you to the Chair of Miftahul Huda Islamic Boarding School Segeran Juntinyuat Indramayu who have given permission, assistance and facilities so that this community service activity can run well. Thank you also to LPPM STKIP Pangeran Dharma Kusuma Segeran Juntinyuat Indramayu for funding and assisting in the implementation of community service activities.

\section{REFERENCES}

[1] Kementerian Kesehatan Republik Indonesia 2015 Rencana Strategis Kementerian Kesehatan tahun 2015-2019 Kementerian Kesehatan Republik Indonesia Jakarta.

[2] Khumayra Z H dan Sulisno M 2012 Perbedaan Pengetahuan dan Sikap Perilaku Hidup Bersih dan Sehat (PHBS) Antara Santri Putra dan Santri Putri J. Nursing Studies 1 197-204.

[3] Kementerian Kesehatan Republik Indonesia 2011 Pedoman Pembinaan Perilaku Hidup Bersih dan Sehat (PHBS) Kementerian Kesehatan Republik Indonesia Jakarta.

[4] Tanshzil S W 2012 Model Pembinaan Pendidikan Karakter pada Lingkungan Pondok Pesantren dalam Membangun Kemandirian dan Disiplin Santri (Sebuah Kajian Pengembangan Pendidikan Kewarganegaraan) Jurnal Penelitian Pendidikan 13.

[5] Permatasari B R, Ridjal A M dan Sukirno A 2014 Penerapan Konsep Permakultur dengan Pendekatan Sosioekologi dalam Membangun Desa Wisata Studi Kasus: Desa Jengglung Harjo, Kabupaten Tulungagung Jurnal RUAS 12.

[6] Natsir M F 2019 Perilaku Hidup Bersih dan Sehat (PHBS) pada Tatanan Rumah Tangga Masyarakat Desa Parang Baddo Jurnal Nasional Ilmu Kesehatan (JNIK) $\mathbf{1}$.

[7] Budiyanto M A K 2002 Dasar-dasar Ilmu Gizi UMM Press Malang.

[8] Maryunani A 2013 Perilaku Hidup Bersih dan Sehat (PHBS) Trans Info Media Jakarta.

[9] Wibisono A F dan Dewi P 2014 Sosialisasi Bahaya Membuang Sampah Sembarangan dan Menentukan Lokasi TPA di Dusun Deles Desa Jagonayan Kecamatan Ngablak Jurnal Inovasi dan Kewirausahaan 3 21-27.

[10] Liem A 2014 Pengaruh media massa, keluarga, dan teman terhadap perilaku merokok remaja di Yogyakarta Makara HubsAsia 18 41-52. 